\title{
Natural Killer Cells From Human Immunodeficiency Virus (HIV)-infected Individuals are an Important Source of CC-Chemokines and Suppress HIV-1 Entry and Replication In Vitro
}

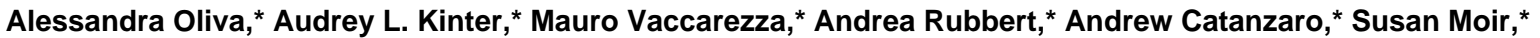 \\ JoAn Monaco, ${ }^{\star}$ Linda Ehler, ${ }^{\star}$ Stephanie Mizell, ${ }^{\star}$ Robert Jackson, ${ }^{\star}$ Yuexia Li, ${ }^{\ddagger}$ Joseph W. Romano, ${ }^{\ddagger}$ and Anthony S. Fauci ${ }^{\star}$ \\ *Laboratory of Immunoregulation, National Institute of Allergy and Infectious Diseases, National Institutes of Health, Bethesda, \\ Maryland 20892; and ${ }^{\ddagger}$ Advanced BioScience Laboratories, Inc., Kensington, Maryland 20895
}

\begin{abstract}
Macrophage inflammatory protein (MIP)- $1 \alpha$, MIP-1 $\beta$, and RANTES (regulated on activation, normal T cell expressed and secreted), which are the natural ligands of the CC-chemokine receptor CCR5, inhibit replication of MT-2negative strains of HIV-1 by interfering with the ability of these strains to utilize CCR5 as a coreceptor for entry in $\mathrm{CD4}^{+}$cells. The present study investigates the capacity of natural killer (NK) cells isolated from HIV-infected individuals to produce CC-chemokines and to suppress HIV replication in autologous, endogenously infected cells as well as to block entry of MT-2-negative HIV into the $\mathrm{CD}^{+} \mathrm{T}$ cell line PM-1. NK cells freshly isolated from HIV-infected individuals had a high number of mRNA copies for MIP- $1 \alpha$ and RANTES. NK cells produced significant amounts of RANTES, MIP- $1 \alpha$, and MIP- $1 \beta$ constitutively, in response to stimulation with IL-2 alone and when they were performing their characteristic lytic activity (K562 killing). After CD16 cross-linking and stimulation with IL-2 or IL-15 NK cells produced CC-chemokines to levels comparable to those produced by anti-CD3-stimulated $\mathrm{CD}^{+} \mathrm{T}$ cells. Furthermore, CD16 cross-linked NK cells suppressed (49-97\%) viral replication in cocultures of autologous CD8/NKdepleted PBMC to a degree similar to that of PHA or antiCD3-stimulated $\mathrm{CDB}^{+} \mathrm{T}$ cells. In $50 \%$ of patients tested, NK-mediated HIV suppression could be abrogated by neutralizing antibodies to MIP- $1 \alpha$, MIP- $1 \beta$ and RANTES; in contrast, $\mathrm{CD8}^{+} \mathrm{T}$ cell-mediated suppression was not significantly overcome upon neutralization of CC-chemokines. Supernatants derived from cultures of CD16 cross-linked NK cells stimulated with IL-2 or IL-15 dramatically inhibited entry of a MT-2-negative strain of HIV, BaL, in the $\mathrm{CD}^{+} \mathrm{CCR5}^{+}$PM-1 $\mathrm{T}$ cell line. These data suggest that activated NK cells may be an important source of CC-chemokines in vivo and may suppress HIV replication by CCchemokine-mediated mechanisms in addition to classic NK-mediated lytic mechanisms. (J. Clin. Invest. 1998. 102: 223-231.) Key words: NK cells • chemokines • HIV • innate immunity $\bullet$ human
\end{abstract}

Dr. Oliva and Dr. Kinter contributed equally to this work.

Address correspondence to Alessandra Oliva, LIR/NIAID/NIH, 10 Center Drive, MSC-1576, Bethesda, MD 20892-1576. Phone: 301496-7590; FAX: 301-402-4122; E-mail: aoliva@atlas.niaid.nih.gov

Received for publication 21 November 1997 and accepted in revised form 21 April 1998.

The Journal of Clinical Investigation

Volume 102, Number 1, July 1998, 223-231

http://www.jci.org

\section{Introduction}

Natural killer (NK) ${ }^{1}$ cells are large granular lymphocytes with innate immune effector capacity and are an important component of the early response against viral infections and neoplastic diseases (1). They do not express T cell receptors, but commonly express a variety of nonexclusive phenotypic markers such as CD16, CD56, CD57, and to some extent CD8. NK cells are able to spontaneously lyse sensitive target cells such as tumor cells and cells infected with viruses or bacteria, as well as to mediate antibody-dependent cellular cytotoxicity (ADCC) via CD16 (Fc $\gamma$ RIII)-Fc interactions (2). It has recently been established that HLA class I molecules inhibit lytic activity of NK cells through a complex series of killer-cell inhibitory receptor (KIR) interactions $(3,4)$. Interestingly, it has also been demonstrated that $\mathrm{T}$ cell function is modulated by similar inhibitory molecules $(3,4)$. It is the absence of a particular HLA class I molecule or changes in the structure of the MHC-peptide complex on a target cell that trigger lytic activities; processes that frequently occur in neoplastic diseases and viral infections.

The role of NK cell activity in controlling the replication and spread of HIV has not been fully delineated. Several studies have correlated high NK cell activity or frequency with either reduced susceptibility of certain individuals to HIV infection (5) or with the control of initial primary viremia in the simian immunodeficiency virus (SIV) model (6). Loss of NK cell activity and frequency has been correlated with HIV disease progression, particularly in individuals with opportunistic infections (7-9).

The finding that certain CC- and CXC-chemokine receptors can be used as coreceptors by different strains of HIV has broadened the role of host factors in the pathogenesis of HIV infection $(10,11)$. The inhibition of entry and replication of MT-2-negative strains of HIV by the CC-chemokines MIP- $1 \alpha$, MIP-1 $\beta$, and RANTES quickly led to the identification of CCR5 as a major coreceptor for such strains (12-17).

The importance of CCR5 expression in determining the susceptibility of individuals to infection with HIV is demonstrated by the rarity of HIV transmission to individuals who are homozygous for the 32-bp deleted CCR5 allele $(18,19)$. In addition, reduced levels of CCR5 expression due to a heterozygous CCR5 genotype appear to result in a slower rate of progression to AIDS in subjects infected with MT-2-negative

1. Abbreviations used in this paper: ADCC, antibody-dependent cellular cytotoxicity; E:T, effector:target; MIP, macrophage inflammatory protein; NASBA, nucleic acid sequence-based amplification; NK, natural killer; RANTES, regulated on activation, normal T cell expressed and secreted; RT, reverse transcriptase. 
HIV strains (20-23). Similarly, it is reasonable to assume that high levels of MIP-1 $\alpha$, MIP-1 $\beta$, and RANTES at sites of HIV infection and replication could limit the availability of CCR5 for use as an HIV coreceptor and thus slow the replication and spread of the MT-2-negative virus in vivo. It is therefore of interest to determine which cell types are important sources of these CC-chemokines and which physiologic stimuli optimize CC-chemokine production.

Recently, NK cells from HIV-uninfected individuals were found to produce MIP-1 $\alpha$ in response to IL-12 plus IL-15 (24). However, the ability of NK cells from HIV-infected subjects to produce $\mathrm{CC}$-chemokines and the effect of NK cell-derived CC-chemokines on HIV replication have not been delineated. The present study investigates the optimal conditions for the secretion of CC-chemokines by NK cells from HIV-infected individuals, the ability of NK cells to suppress autologous virus replication, and the ability of NK cell-derived supernatants to block MT-2-negative HIV-1 entry into susceptible target cells.

\section{Methods}

Cellular populations. PBMCs were obtained by apheresis of $20 \mathrm{HIV}$ infected individuals $\left(\mathrm{CD}^{+}{ }^{+} \mathrm{T}\right.$ cell count: range $154-1433 / \mu \mathrm{l}$; mean 558/ $\mu 1$ ); cells were separated over Ficoll-Hypaque density gradients. Three populations of cells were isolated: $(a)$ NK cells were obtained from nonadherent PBMC (collected after $1 \mathrm{~h}$ adherence at $37^{\circ} \mathrm{C}$ ) by positive selection with anti-CD16 (Immunotech, Westbrook, ME) and anti-CD56 (PharMingen, San Diego, CA) coupled goat antimouse IgG beads (Dynal, Great Neck, NY). Positively selected cells were cultured overnight at $37^{\circ} \mathrm{C}$ to detach them, incubated for $1 \mathrm{~h}$ at $4^{\circ} \mathrm{C}$ and then depleted of $\mathrm{CD}^{+}$cells using immunomagnetic beads (Dynal). Alternatively, NK cells were obtained by negative selection with an NK cell isolation kit from Miltenyi Biotec (Auburn, CA). Purified NK cells had $<5 \%$ contamination with $\mathrm{CD} 3^{+}, \mathrm{CD} 14^{+}, \mathrm{CD} 19^{+}$ cells as measured by FACS analysis. (b) $\mathrm{CD}^{+}$PBMC subsets were obtained by positive selection with CD8 beads (Dynal) and detached with Detachabeads (Dynal) or by incubation at $37^{\circ} \mathrm{C}$ overnight. $\mathrm{CD}^{+} \mathrm{T}$ cells $\left(>95 \% \mathrm{CD}^{+} \mathrm{CD}^{+}\right)$were obtained after further depletion of $\mathrm{CD} 16^{+} / \mathrm{CD} 56^{+}$cells with immunomagnetic beads. Alternatively, $\mathrm{CD} 8^{+} \mathrm{T}$ cells were obtained by negative selection with a $\mathrm{CD} 8^{+}$ $\mathrm{T}$ cell isolation kit from Miltenyi Biotec. (c) CD8/NK-depleted PBMCs were obtained using $\mathrm{CD} 8$ beads and $\mathrm{CD} 16^{+} / 56^{+}$beads.

CC-chemokine $m R N A$ expression. NK cells and $\mathrm{CD} 8^{+} \mathrm{T}$ cells, isolated by negative selection from PBMC of HIV-infected and uninfected individuals, immediately after Ficoll-Hypaque separation were lysed with a buffer containing guanidine thiocyanate and Triton X-100 and frozen at $-80^{\circ} \mathrm{C}$. Levels of mRNA for CC-chemokines were determined by using a transcription-based amplification system: nucleic acid sequence-based amplification (NASBA) (25). Briefly, first strand synthesis of cDNA was accomplished by primer 1 (containing the T7RNA polymerase promoter sequence) and avian myeloblastosis virus reverse transcriptase (AMV-RT). The RNA of the heteroduplex (RNA-DNA) was degraded by RNAse $\mathrm{H}$, the synthesis of the second strand of cDNA was performed using primer 2 and AMV-RT, and RNA transcripts were produced by T7-RNA polymerase. Various concentrations of synthetic RNAs derived from the cDNA sequence of MIP-1 $\alpha$ and RANTES were used as internal standards in the reaction. Signal was detected after hybridization with a ruteniumlabeled probe and quantified by measuring chemiluminiscence (26). The primer pairs and probes are described elsewhere (Romano, J.W., R.N. Shurtliff, K.G. Williams, M. Kaplan, and C. Ginocchio, manuscript in preparation).

CC-chemokine production. Positively selected $\mathrm{CD} 8^{+} \mathrm{T}$ cells and CD16 cross-linked NK cells were cultured $\left(10^{6} / \mathrm{ml}\right)$ in RPMI-1640s (supplemented with $1 \mathrm{mM}$ antibiotics, glutamine, and Hepes buffer) with $10 \%$ FBS (BioWhittaker, Walkersville, MD). Cultures were treated with IL-2 $(100 \mathrm{U} / \mathrm{ml}$; Boehringer Mannheim, Indianapolis, IN), IL-12 (100 U/ml; R\&D, Minneapolis, MN), or IL-15 (100 U/ml, $\mathrm{R} \& \mathrm{D})$. Certain cultures of $\mathrm{CD}^{+} \mathrm{T}$ cells were stimulated with phytohemagglutinin (PHA, $3 \mu \mathrm{g} / \mathrm{ml}$; Sigma Chemical Co., St. Louis, MO) alone or with PHA $(3 \mu \mathrm{g} / \mathrm{ml})+$ IL-2 $(20 \mathrm{U} / \mathrm{ml})$ or with anti-CD3 (mouse ascites, 1:4,000 dilution) + IL-2 $(20 \mathrm{U} / \mathrm{ml})$. Alternatively, negatively selected NK cells were cultured in medium alone or with IL-2 $(100 \mathrm{U} / \mathrm{ml})$, in untreated culture plate wells or in wells coated with immobilized CD16 antibody (5 $\mu \mathrm{g} / \mathrm{ml}$; Immunotech) or isotypic mouse $\mathrm{IgG}$ antibody (5 $\mu \mathrm{g} / \mathrm{ml}$; Sigma Chemical Co.). Similarly, negatively selected $\mathrm{CD}^{+} \mathrm{T}$ cells were cultured in medium alone or with IL-2 $(100 \mathrm{U} / \mathrm{ml})$, in untreated culture plate wells or in wells coated with immobilized anti-CD3 (mouse ascites, 1:400 dilution, equivalent to $25 \mu \mathrm{g} / \mathrm{ml})$ or isotypic IgG antibody $(25 \mu \mathrm{g} / \mathrm{ml}$, Sigma Chemical Co.). Supernatants were collected at different time points $(18 \mathrm{~h}, 3,5,7$ and $11 \mathrm{~d}$ after stimulation) and assayed by ELISA for production of MIP-1 $\alpha$, MIP-1 $\beta$, and RANTES (R\&D).

Cytolytic assay. NK cells isolated by negative selection from HIV-infected individuals were tested for their lytic activity against K562 cells (NK-sensitive cell line). Effector cells (purified NK cells) were incubated overnight at $37^{\circ} \mathrm{C}$ in culture flasks at a concentration of $1 \times 10^{6} / \mathrm{ml}$ in RPMI-1640s with $10 \%$ FBS and IL-2 $(20 \mathrm{U} / \mathrm{ml})$. K562 cells were labeled with ${ }^{51} \mathrm{Cr}$ for $1 \mathrm{~h}$ at $37^{\circ} \mathrm{C}\left(2 \times 10^{6}\right.$ cells labeled with $100 \mu \mathrm{Ci}$ ), washed three times and plated in 96 -well $\mathrm{V}$ bottom plates at $5 \times 10^{3} /$ well. Effector cells were added to a constant number of target cells at the following effector:target (E:T) ratios: 10:1, 5:1, and 2.5:1. After $4 \mathrm{~h}$ of incubation at $37^{\circ} \mathrm{C}$, supernatants were harvested and counted on a $\gamma$-counter (Wallac Inc., Gaithersburg, MD). The percentage of target lysis was calculated from the following formula:

\section{$\frac{E-S}{M-S}$}

where $\mathrm{E}=$ experimental ${ }^{51} \mathrm{Cr}$ release; $\mathrm{S}=$ spontaneous release in the presence of culture medium with no NK cells present, and $\mathrm{M}=$ maximal release from target cells treated with detergent (BRIJ 35; Sigma Chemical Co.). Each assay was performed in duplicate with unlabeled target cells and supernatants collected at $4 \mathrm{~h}$ for analysis of MIP- $1 \alpha$, MIP-1 $\beta$, and RANTES secretion by ELISA (R\&D).

Suppression of HIV replication. CD8/NK-depleted PBMC were cultured $\left(10^{6} / \mathrm{ml}\right)$ in RPMI-1640s supplemented with $10 \%$ FBS alone or with various proportions of autologous $\mathrm{CD}^{+} \mathrm{T}$ or CD16 crosslinked NK effector cells (E:T ratios $=1: 2,1: 10,1: 50)$. The cultures were stimulated with anti-CD3 (mouse ascites, 1:4,000 dilution) and IL-2 (20 U/ml; Boehringer Mannheim) or with phytohemagglutinin (PHA, $3 \mu \mathrm{g} / \mathrm{ml}$; Sigma), IL-2 (20 U/ml), and IL-4 (5 ng/ml; R\&D). Supernatants were harvested (2 times/wk) and tested for HIV replication either by reverse transcriptase (RT) assay, as previously described (27), or by p24 ELISA (DuPont, Newton, CT). In certain cultures, a combination of neutralizing antibodies directed against CC-chemokines (goat polyclonal anti-MIP- $1 \alpha, 50 \mu \mathrm{g} / \mathrm{ml}$; goat polyclonal anti-MIP-1 $\beta, 50 \mu \mathrm{g} / \mathrm{ml}$; monoclonal anti-RANTES, $10 \mu \mathrm{g} / \mathrm{ml}$; $\mathrm{R} \& \mathrm{D})$ or goat IgG isotype control $(110 \mu \mathrm{g} / \mathrm{ml} ; \mathrm{R} \& \mathrm{D})$ were added.

Phenotyping of HIV primary isolates: MT-2 assay. $100 \mu \mathrm{l}$ of culture supernatant harvested during peak HIV production from CD8/ NK-depleted PBMC cultures alone as described above was added to $10^{5}$ MT-2 cells in duplicate in 96-well plates and cultured overnight at $37^{\circ} \mathrm{C}$. Cultures were then fed with fresh media (RPMI-1640s plus $10 \%$ FBS). Culture supernatants were harvested and cultures refed and monitored for syncytium formation and RT production over a 3-wk period.

PCR for early HIV transcripts. PM-1 (12) cells $\left(4-5 \times 10^{5}\right.$ cells/ test) were incubated for $30 \mathrm{~min}$ with either medium, a combination of CC-chemokines (MIP- $1 \alpha$, MIP- $1 \beta$, and RANTES each at the equal concentrations of 200,30 , or $5 \mathrm{ng} / \mathrm{ml}$ ) or with supernatants derived either from CD16 cross-linked NK cells stimulated with IL-2, IL-12, or IL-15 (100 U/ml), or from CD8 ${ }^{+}$T cells stimulated with PHA $(3 \mu \mathrm{g} / \mathrm{ml})$ plus IL-2 $(20 \mathrm{U} / \mathrm{ml})$. PM-1 cells were then acutely infected with either the MT-2-negative BaL (Advanced Biotechnologies Incorporated, 
Columbia, MD) or the MT-2-positive IIIB (Advanced Biotechnologies Incorporated) strain of HIV-1. After 6-7 h of incubation at $37^{\circ} \mathrm{C}$, the cells were washed three times in PBS and the pellets frozen at $-70^{\circ} \mathrm{C}$. Semiquantitative PCR for early HIV transcripts using primers for the long terminal repeat (LTR) region (M667 and AA55; Lofstrand Labs Limited, Gaithersburg, MD) and CG24 probe (Lofstrand Labs Limited) was performed on cell lysates as previously described (28). HLA primers (QH26 and QH27; Lofstrand Labs Limited) and probe (QH64; Lofstrand Labs Limited) were used to standardize for cell numbers. Probes were labeled with ${ }^{32} \mathrm{P}-\mathrm{ATP}$ (Du Pont NEN, Newton, CT) and hybridized to amplified samples. The samples were run on polyacrylamide gels and exposed overnight in a phosphoimager cassette. Results were analyzed with Image Quant software (Molecular Dynamics, Sunnyvale, CA). The number of DNA copies per $10^{5}$ cells was obtained comparing the radioactive signals from samples to those from 10 -fold dilutions $\left(10^{3}-10^{0}\right)$ of the chronically HIV-infected cell line ACH2. The results of this early RT transcript detection assay are referred to as HIV entry. It should be noted that events occurring after entry, such as rates of initiation of reverse transcription, can not be excluded as contributing factors.

\section{Results}

CC-chemokine mRNA expression in NK cells and $C D 8^{+} T$ cells. $\mathrm{NK}$ and $\mathrm{CD}^{+} \mathrm{T}$ cells were negatively selected from the peripheral blood of HIV-infected and uninfected individuals and analyzed immediately for MIP- $1 \alpha$ and RANTES mRNA using the NASBA nucleic acid amplification technique. As shown in Fig. 1, the number of MIP- $1 \alpha$ mRNA copies detected in NK cells $\left(\right.$ mean $\left.=96.2 \times 10^{4} \pm 39.535\right)$ was significantly greater $(P<0.05)$ than the number detected in $\mathrm{CD}^{+} \mathrm{T}$ cells $\left(\right.$ mean $\left.=17.747 \times 10^{4} \pm 8.246\right)$ among HIV-infected individuals. Although there were small differences between NK cells and $\mathrm{CD}^{+} \mathrm{T}$ cells in numbers of MIP- $1 \alpha$ mRNA copies among HIV uninfected individuals and in numbers of RANTES copies among both HIV-infected and uninfected individuals, these differences were not statistically significant.

$N K$ cell lytic activity against K562 cells is associated with induction of CC-chemokine production. Among the in vivo activities of NK cells is the MHC nonrestricted lysis of certain tumor cells. Therefore, it was of interest to determine the levels of CC-chemokines produced upon recognition and lysis by $\mathrm{NK}$ cells of sensitive targets such as the K562 cell line. A standard lytic assay based on ${ }^{51} \mathrm{Cr}$ release was performed using negatively selected NK cells from seven different HIV-infected individuals. NK cells from five of seven donors mediated significant specific killing at various effector:target ratios (10:1, 5:1, and 2.5:1) (Fig. 2). NK cells from the remaining two donors failed to lyse target cells $(<10 \%$ specific lysis at the highest E:T ratio [10:1]) (data not shown).

Supernatants harvested after $4 \mathrm{~h}$ from duplicate cultures containing unlabeled targets (see Methods) were tested by ELISA to assess the levels of CC-chemokines induced from NK cells during activation of lytic functions. K562 (target cells) cultured alone or lysed by detergent failed to produce detectable levels of CC-chemokines (data not shown). NK cells exhibiting efficient target cell killing activity consistently produced significantly higher levels of MIP- $1 \alpha$ and MIP- $1 \beta$ as compared to NK cells alone or NK cells that failed to lyse target cells (Fig. 3, $A-C$ ). The fold increase in chemokine production by NK cells after recognition of target cells in comparison to NK cells alone ranged from 3 to 14 for MIP-1 $\alpha$, from 10 to 48 for MIP-1 $\beta$, and from 11 to 68 for RANTES. The range of
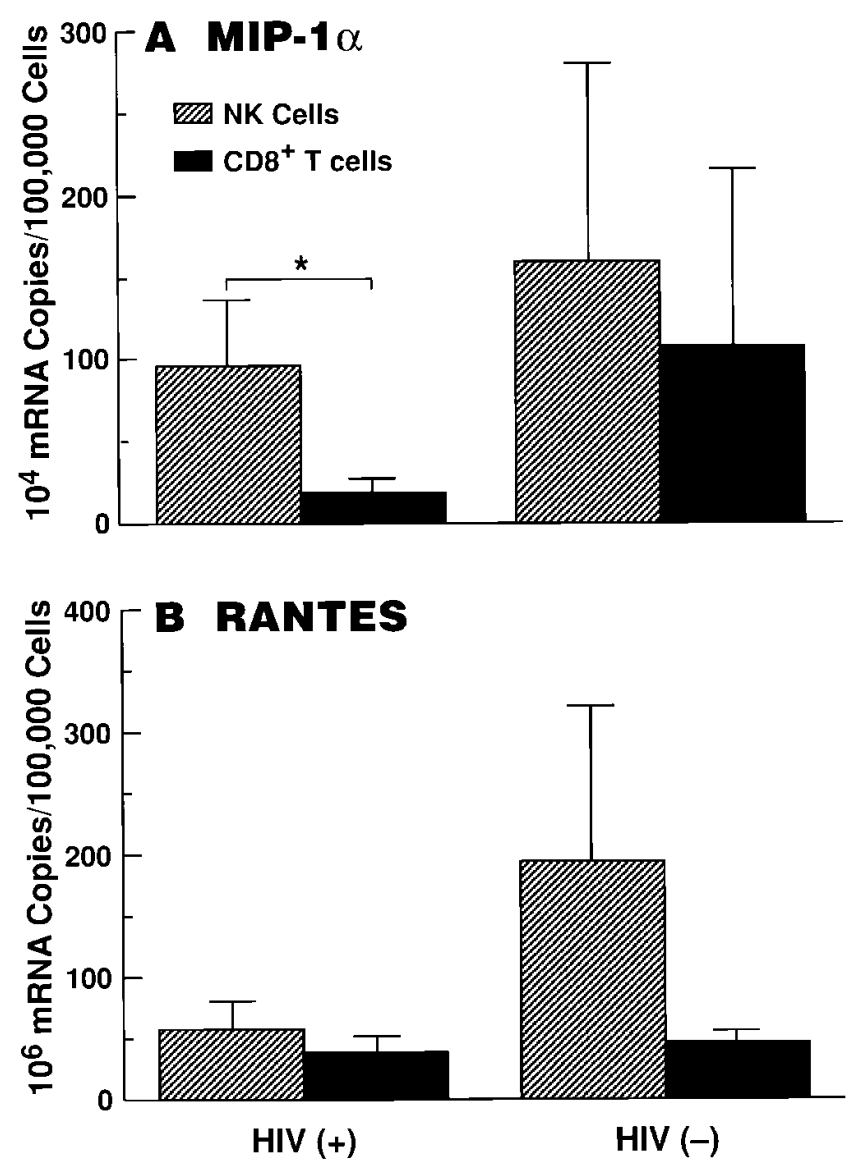

Figure 1. Quantification of mRNA for MIP-1 $\alpha$ and RANTES in NK and $\mathrm{CD} 8^{+} \mathrm{T}$ cells from HIV-infected and uninfected individuals. $\mathrm{CD}^{+} \mathrm{T}$ cells and NK cells were isolated by negative selection from HIV-infected $(n=6)$ or uninfected $(n=2)$ individuals and immediately lysed and kept frozen $\left(-80^{\circ} \mathrm{C}\right)$ until tested. Quantification of mRNA for $(A)$ MIP- $1 \alpha$ and $(B)$ RANTES was performed using a transcription-based amplification system: nucleic acid sequencebased amplification (NASBA) technique. The values represent the mean and standard error of mRNA copy number detected in 100,000 cells. Statistical analysis to determine $P$ values was performed with the Student's $t$ test $(* P<0.05)$.

RANTES levels produced by NK cells of different donors was wider than the range observed for MIP- $1 \alpha$ and MIP-1 $\beta$ levels (Fig. $3 \mathrm{C}$ ); this factor likely contributed to the lack of statistically significant differences in RANTES levels among the three NK populations.

Effect of CD3 or CD16 cross-linking on production of CC-chemokines by CD $8^{+} T$ cells and NK cells, respectively. It is well established that cross-linking of CD16 on the surface of NK cells stimulates lytic activity and upregulates expression of several cytokines (29). It is also well known that CD3 crosslinking on the surface of $\mathrm{CD}^{+}$and $\mathrm{CD} 4^{+} \mathrm{T}$ cells mimics antigenic stimulation by inducing cellular activation, proliferation, and cytokine production (30). Accordingly, the effect of CD3 and CD16 cross-linking on the production of CC-chemokines by $\mathrm{CD}^{+} \mathrm{T}$ cells and NK cells, respectively, was investigated. The results are summarized in Table I. In the absence of receptor-specific cross-linking ( $\mathrm{mIgG}$ control), NK cells secreted higher levels of all three CC-chemokines than did $\mathrm{CD}^{+} \mathrm{T}$ cells isolated from the same individuals, both constitutively 


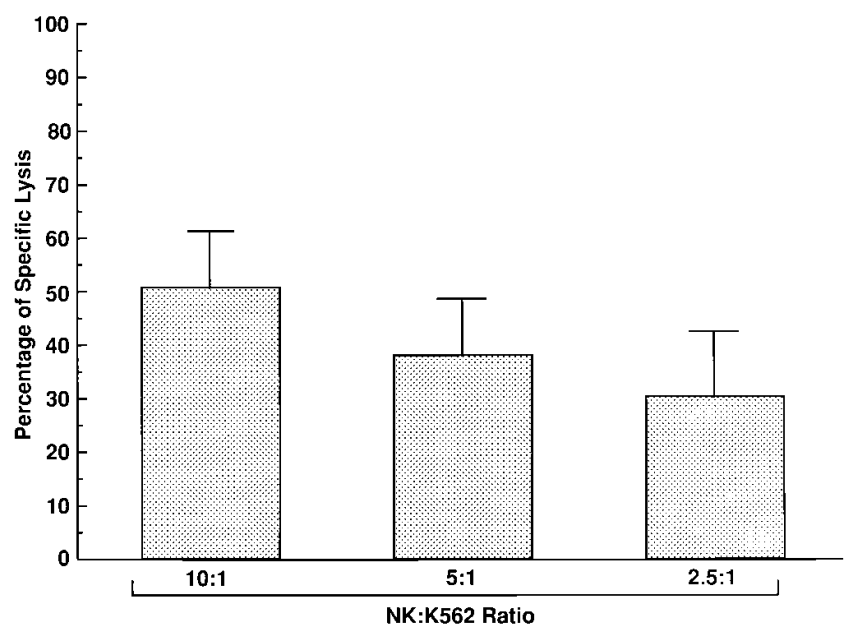

Figure 2. NK cell-mediated lytic activity against K562 cells. NK cells isolated by negative selection from HIV-infected individuals $(n=5)$ were incubated with $\mathrm{K} 562$ cells labeled with ${ }^{51} \mathrm{Cr}$ at various effector: target ratios. The supernatants were collected at $4 \mathrm{~h}$ and counted on a $\gamma$-counter. The data represent the mean value and standard error of percentage of specific lysis of K562 at effector:target (E:T) ratios of 10:1, 5:1, and 2.5:1.

and in response to IL-2. Cross-linking of CD16 on NK cells significantly increased $\mathrm{CC}$-chemokine secretion as compared to cells treated with $\mathrm{mIgG}$ control mAb (absence of IL-2), while cross-linking of $\mathrm{CD} 3$ on $\mathrm{CD}^{+} \mathrm{T}$ cells in the same culture conditions induced a significantly higher production of MIP-1 $\beta$, but not of MIP- $1 \alpha$ and RANTES. The lack of statistically significant upregulation of these two CC-chemokines upon CD3 cross-linking of $\mathrm{CD}^{+} \mathrm{T}$ cells is likely due to high variability among donors. Under the optimal conditions of CD16 or CD3 cross-linking plus IL-2, both $\mathrm{NK}$ and $\mathrm{CD}^{+} \mathrm{T}$ cells produced significantly higher levels of all three CC-chemokines as compared to cells in control conditions (mIgG, absence of IL-2). Of interest, under these optimal stimulatory conditions, NK cells secreted significantly higher levels of MIP-1 $\alpha$ and RANTES than did $\mathrm{CD}^{+}$T cells. The $P$ values regarding the statistical analyses of the CC-chemokine levels detected in the cell-free supernatants are shown in Table I. CC-chemokine production in the various culture conditions did not correlate with levels of cellular proliferation (data not shown).

Effect of IL-2, IL-12, and IL-15 on CC-chemokine production by CD16 cross-linked NK cells. Among the most effective inducers of NK cell lytic activity and cytokine secretion are the immunomodulatory cytokines IL-2, IL-12, and IL-15 (31-33). Recently, it has been demonstrated that the combination of IL-12 plus IL-15 induces MIP- $1 \alpha$ production by NK cells isolated from HIV-uninfected individuals (24). Considering these observations and the continued interest in cytokine-based immunotherapy for HIV disease, IL-2, IL-12, and IL-15 were compared for their ability to stimulate $\mathrm{CC}$-chemokine production from CD16 cross-linked NK cells isolated from HIVinfected individuals. The peak of CC-chemokine production occurred at day 3 or 5 after stimulation (data not shown). As seen in Fig. 4, IL-2 and IL-15 were more effective in inducing CC-chemokine production in CD16 cross-linked NK cells than was IL-12, with the exception of RANTES, which was secreted at comparable levels in response to IL-2, IL-12, and IL-15.
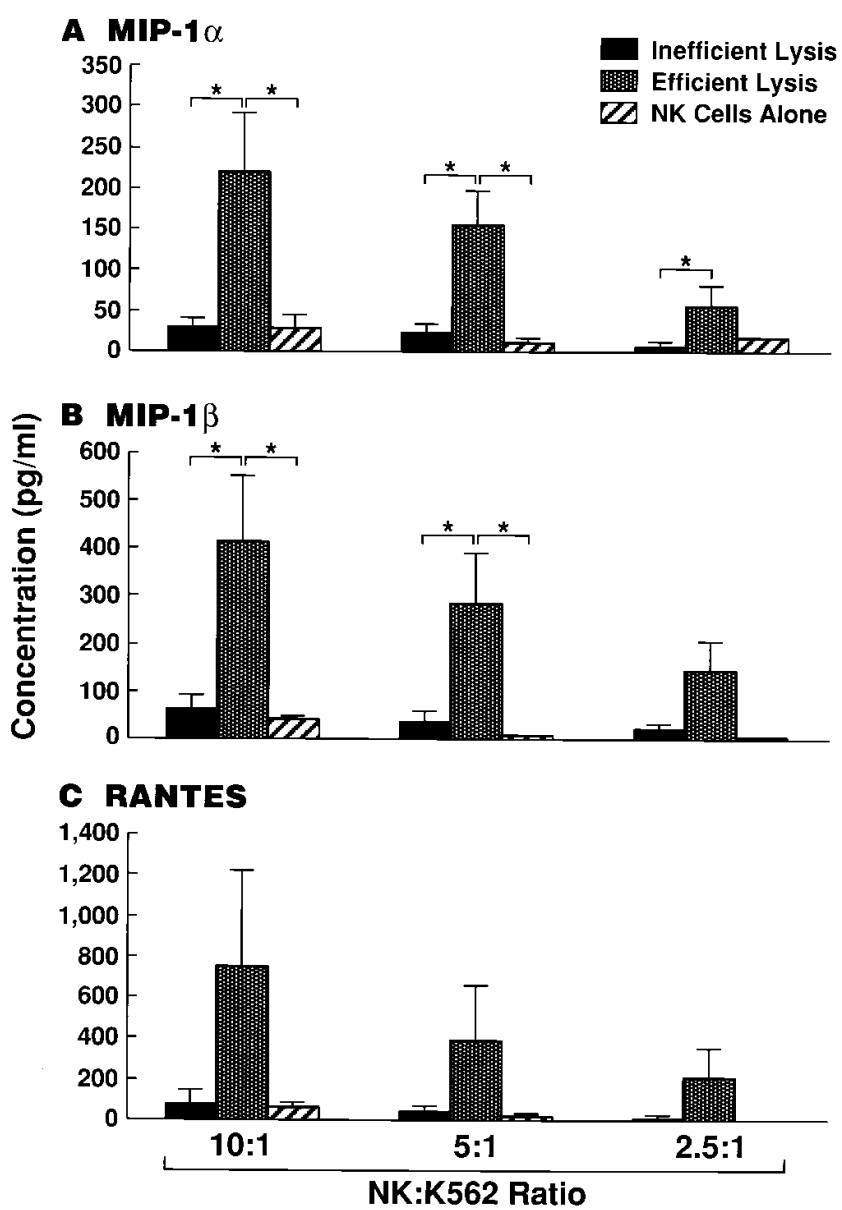

Figure 3. CC-chemokine production by NK cells driven by recognition of the NK-sensitive cell line, K562. Duplicate K562 lytic assays were performed using unlabeled target cells and supernatants were harvested to determine secretion of $(A)$ MIP- $1 \alpha,(B)$ MIP- $1 \beta$, and $(C)$ RANTES by ELISA. The supernatants tested were derived from cultures of NK cells and K562 cells in which the lysis was inefficient (percentage of lysis $<10$ at E:T 10:1, $n=2$ ), from cultures of NK cells and K562 cells in which the lysis was efficient (percentage of lysis $>10$ at E:T 10:1, $n=5)$ and from cultures of NK cells alone $(n=2)$. The results are expressed as mean value and standard error of the concentration of CC-chemokines detected in the supernatants harvested after $4 \mathrm{~h}$ of incubation. Statistical analysis to determine $P$ values was performed with the Student's $t$ test $(* P<0.05)$.

Suppression of HIV replication in an autologous coculture system. To determine the ability of NK cells to suppress HIV replication in vitro, CD8/NK-depleted PBMC from HIVinfected subjects were cultured in the absence or presence of various numbers of autologous $\mathrm{CD}^{+} \mathrm{T}$ cells or CD16 crosslinked NK cells and then stimulated with anti-CD3+IL-2. Autologous NK cells were able to suppress in vitro HIV replication in $75 \%(6 / 8)$ of the patients tested at the E:T ratio of 1:2. Significant HIV suppression ( $>30 \%$ reduction of the RT or p24 values detected in the cultures of target cells alone) was usually observed also at the E:T ratio of 1:10, but was lost at the lowest E:T ratio of 1:50 (Fig. 5). Similar efficiency of HIV suppression was observed in parallel cultures containing $\mathrm{CD}^{+}$ T cell effectors (Fig. 5). NK cell-mediated HIV suppression ranged from 49 to $97 \%$ at the E:T ratio of 1:2. Virus isolated 


\begin{tabular}{|c|c|c|c|c|c|c|}
\hline & \multicolumn{2}{|c|}{ MIP- $1 \alpha$} & \multicolumn{2}{|c|}{ MIP-1 $\beta$} & \multicolumn{2}{|c|}{ RANTES } \\
\hline & NK cells & $\mathrm{CD} 8^{+} \mathrm{T}$ cells & NK cells & $\mathrm{CD} 8^{+} \mathrm{T}$ cells & NK cells & $\mathrm{CD}^{+} \mathrm{T}$ cells \\
\hline \multicolumn{7}{|l|}{ Untreated } \\
\hline mIgG X-link & $345.8 \pm 141.9$ (a) & $7.8 \pm 7.8\left(\mathrm{a}^{\prime}\right)$ & $177 \pm 51(b)$ & $11.8 \pm 9.1\left(\mathrm{~b}^{\prime}\right)$ & $487.8 \pm 193.2(\mathrm{c})$ & $4.24 \pm 1.5\left(\mathrm{c}^{\prime}\right)$ \\
\hline CD16 or CD3 X-link & $2338.8 \pm 195.6(\mathrm{~d})$ & $1836.2 \pm 980.9\left(\mathrm{~d}^{\prime}\right)$ & $8703.4 \pm 853.4(\mathrm{e})$ & $6420.6 \pm 1925.1\left(\mathrm{e}^{\prime}\right)$ & $2929.6 \pm 473.8$ (f) & $934 \pm 503.8\left(\mathrm{f}^{\prime}\right)$ \\
\hline \multicolumn{7}{|c|}{ IL-2 (100 U/ml) } \\
\hline mIgG X-link & $4995.2 \pm 1075.5(\mathrm{~g})$ & $74.2 \pm 48.2\left(\mathrm{~g}^{\prime}\right)$ & $8599 \pm 1139.5(h)$ & $216.6 \pm 210.1\left(\mathrm{~h}^{\prime}\right)$ & $1800.25 \pm 423.5(\mathrm{i})$ & $16.6 \pm 14.6\left(i^{\prime}\right)$ \\
\hline CD16 or CD3 X-link & $13176.8 \pm 710.4(\mathrm{j})$ & $7048.4 \pm 1968.8\left(\mathrm{j}^{\prime}\right)$ & $9863.4 \pm 1101(\mathrm{k})$ & $10661 \pm 556.7\left(\mathrm{k}^{\prime}\right)$ & $7511 \pm 1673.5(1)$ & $2600.4 \pm 1123.8\left(1^{\prime}\right)$ \\
\hline
\end{tabular}

The values $(\mathrm{pg} / \mathrm{ml})$ represent the mean \pm standard error of the levels of CC-chemokine detected in the cell-free supernatants obtained from the cultures of cells isolated from five different HIV-infected individuals. Statistical analyses performed with the Student's $t$ test, paired samples, gave the following results: $\mathrm{a}^{\prime}$ vs $\mathrm{g}^{\prime}, \mathrm{a}^{\prime}$ vs $\mathrm{d}^{\prime}, \mathrm{b}^{\prime}$ vs $\mathrm{h}^{\prime}, \mathrm{h}$ vs k, e vs k, $\mathrm{c}^{\prime}$ vs $\mathrm{i}^{\prime}, \mathrm{c}^{\prime}$ vs $\mathrm{f}^{\prime}$ and $\mathrm{k}$ vs k': $P=$ not significant; a vs a $\mathrm{a}^{\prime}, \mathrm{g}^{\prime}$ vs $\mathrm{j}^{\prime}, \mathrm{d}^{\prime}$ vs $\mathrm{j}^{\prime}, \mathrm{b}$ vs $\mathrm{b}^{\prime}, \mathrm{b}^{\prime}$ vs $\mathrm{e}^{\prime}, \mathrm{e}^{\prime}$ vs k', c vs c', i vs i', c vs i, i vs l, i' vs $\mathrm{l}^{\prime}, \mathrm{f}$ vs $1, \mathrm{f}^{\prime}$ vs $\mathrm{l}^{\prime}, \mathrm{f}$ vs $\mathrm{f}^{\prime}$, and $\mathrm{l}$ vs $\mathrm{l}^{\prime}: P<0.05 ; \mathrm{g}$ vs $\mathrm{g}^{\prime}$, a vs g, a vs d, $\mathrm{d}$ vs d' and $\mathrm{j}$ vs $\mathrm{j}^{\prime}: P<0.01 ; \mathrm{g}$ vs $\mathrm{j}$, h vs h', b vs h, b vs e and e vs $\mathrm{e}^{\prime}: P<0.001 ; \mathrm{d}$ vs $\mathrm{j}$ and $\mathrm{h}^{\prime} \mathrm{vs} \mathrm{k}^{\prime}: P<0.0001$.

from one of the two individuals who failed to demonstrate NK cell-mediated HIV suppression was found to be a syncytiuminducing/MT-2-positive strain; such strains have been shown to be insensitive to inhibition by CC-chemokines (12). There

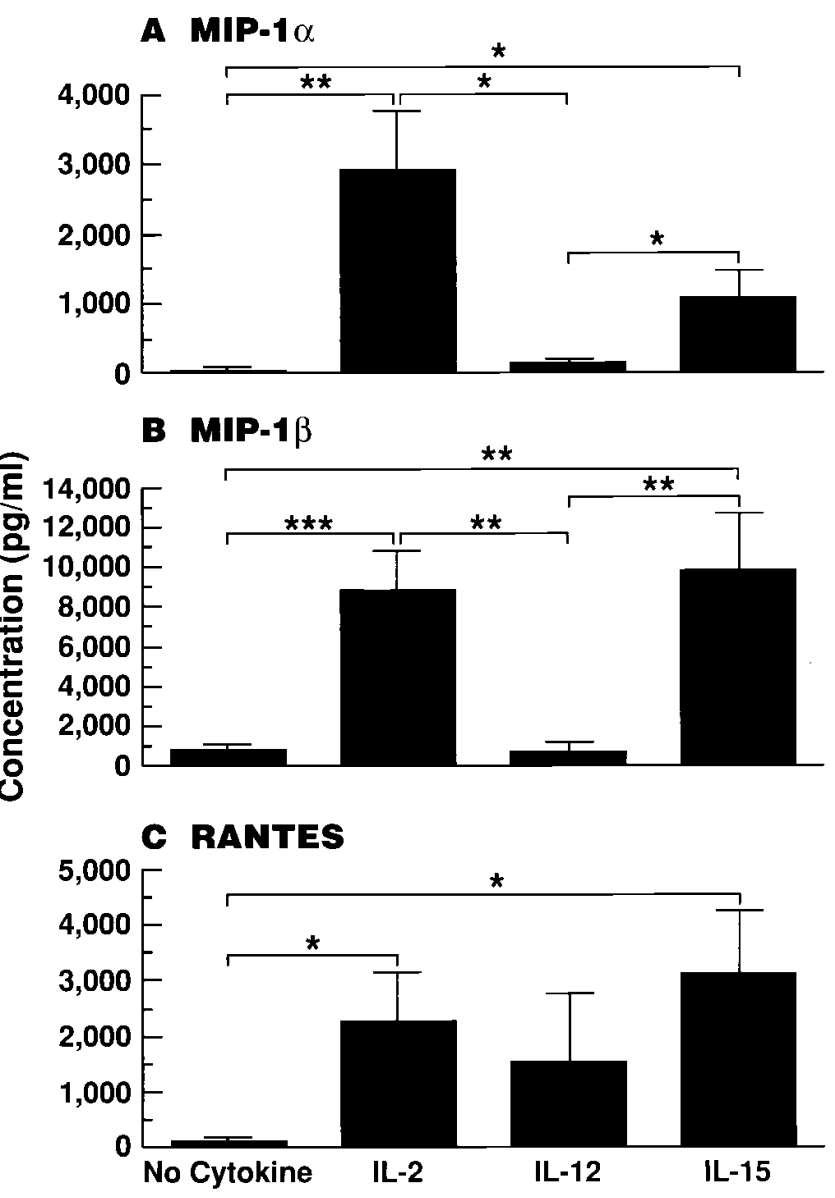

Figure 4. CC-chemokine production by CD16 cross-linked NK cells in response to IL-2, IL-12, and IL-15. CD16 cross-linked NK cells were cultured in medium alone (No cytokine) $(n=4)$, IL-2 $(100 \mathrm{U} / \mathrm{ml})$ $(n=19), \mathrm{IL}-12(100 \mathrm{U} / \mathrm{ml})(n=11)$ or IL-15 $(100 \mathrm{U} / \mathrm{ml})(n=11)$ for 3-5 d and cell-free supernatants were evaluated for production of (A) MIP-1 $\alpha,(B)$ MIP-1 $\beta$, and $(C)$ RANTES. Statistical analysis to determine $P$ values was performed with the Student's $t$ test $(* P<$ $0.05 ; * * P<0.01 ; * * * P<0.001)$. was no statistically significant correlation between the ability of NK cells to suppress endogenous HIV replication in vitro and the $\mathrm{CD} 4^{+} \mathrm{T}$ cell count or the stage of disease of the individuals tested.

Several reports have demonstrated that both soluble and cell contact-dependent factors contribute to the HIV-suppressive effects of $\mathrm{CD}^{+} \mathrm{T}$ cells (34-38). To establish the contribution of CC-chemokines to the HIV-suppressive effects of NK cells, in certain experiments a combination of neutralizing anti-CC-chemokine antibodies was added to the cultures of CD8/NK-depleted PBMCs to which either NK cells or CD8 ${ }^{+}$ $\mathrm{T}$ cells had been added back. In $50 \%$ of the cultures in which NK-mediated HIV suppression was observed, the addition of neutralizing antibodies to MIP- $1 \alpha$, MIP-1 $\beta$, and RANTES completely restored HIV replication to control levels; in the other $50 \%$ of patients, neutralizing antibodies to CC-chemokines resulted in incomplete abrogation of the HIV-suppressive effect (data not shown). In contrast, $\mathrm{CD}^{+} \mathrm{T}$ cell-mediated suppression was only minimally overcome by neutralizing CCchemokines in cultures from all patients tested (Fig. 6).

Effect of $\mathrm{NK}$ and $\mathrm{CD}^{+} \mathrm{T}$ cell-derived $\mathrm{CC}$-chemokines on HIV entry. To further demonstrate the HIV inhibitory activity of NK cell-derived CC-chemokines, supernatants from cultures of purified $\mathrm{NK}$ cells and $\mathrm{CD}^{+} \mathrm{T}$ cells were assessed for their ability to inhibit HIV entry into a $\mathrm{CD}^{+}$cellular target using a PCR based technique. Preincubation of target PM-1 cells with supernatants derived from CD16 cross-linked NK cells stimulated with IL-2, IL-12, or IL-15 inhibited the entry of the MT-2-negative BaL strain (Fig. 7) but not the MT-2positive strain, IIIB (data not shown). Supernatants from IL-2- or IL-15-stimulated NK cells were significantly more effective than those derived in IL-12 conditions and were equally potent in suppressing MT-2-negative HIV entry as were supernatants from PHA-stimulated $\mathrm{CD}^{+} \mathrm{T}$ cells.

\section{Discussion}

It has been well established that NK cells lyse HIV-infected cells by natural or antibody-dependent cytotoxic mechanisms (38) however, the ability of NK cells to suppress HIV entry and replication by soluble factors has not been described. The present study demonstrates that NK cells isolated from HIVinfected subjects are capable of producing high levels of the CC-chemokines MIP- $1 \alpha$, MIP- $1 \beta$, and RANTES. MIP- $1 \alpha$ and 


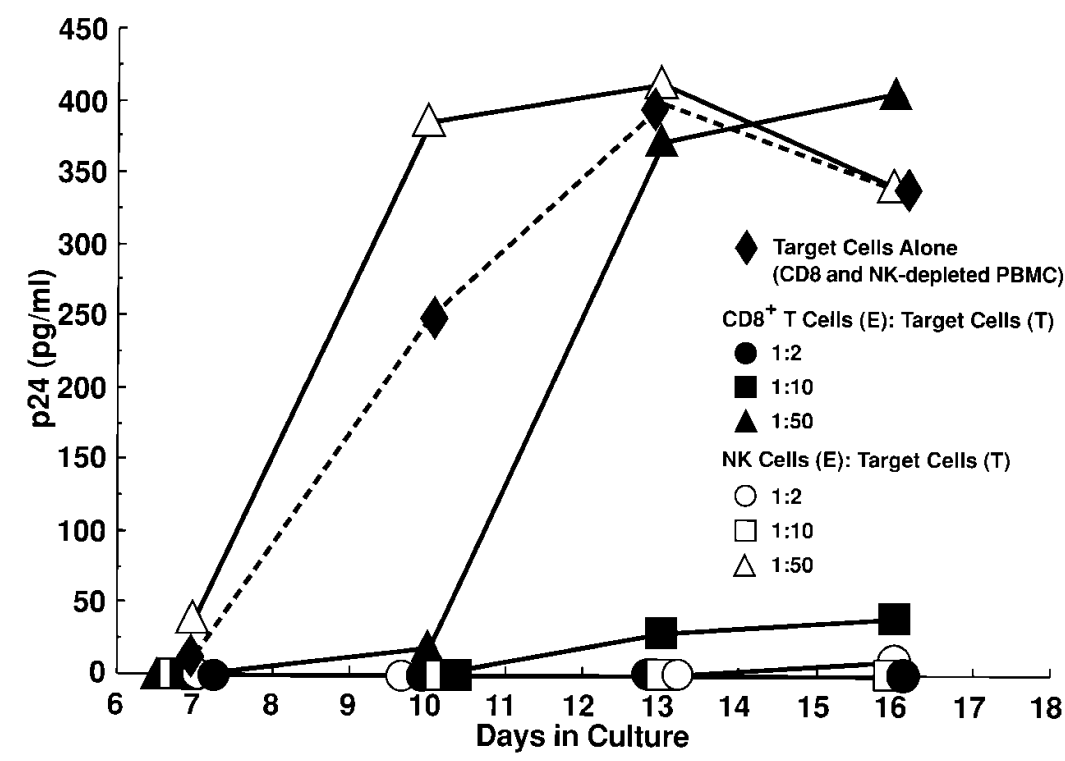

Figure 5. CD16 cross-linked NK cells suppress HIV replication in autologous cocultures with similar efficiency as do $\mathrm{CD}^{+} \mathrm{T}$ cells. CD8/NK-depleted PBMCs from HIV-infected individuals were cultured with anti-CD3 (mouse ascites, 1:4,000 dilution) + IL-2 (20 $\mathrm{U} / \mathrm{ml}$ ) in the absence of effector $\mathrm{CD} 8^{+} \mathrm{T}$ cells or $\mathrm{NK}$ cells (dashed line), or in the presence of autologous $\mathrm{CD}^{+} \mathrm{T}$ cells (closed symbols), or autologous CD16 cross-linked NK cells (open symbols) at various ratios $(1: 2,1: 10$, or 1:50). Similar results were obtained in cultures stimulated with PHA $(3 \mu \mathrm{g} / \mathrm{ml})+\mathrm{IL}-2(20$ $\mathrm{U} / \mathrm{ml})+\mathrm{IL}-4(5 \mathrm{ng} / \mathrm{ml})$. These data are representative of six independent analyses.
RANTES mRNA were detected in freshly isolated NK cells at equal or greater copy numbers than in $\mathrm{CD}^{+} \mathrm{T}$ cells isolated from the same individuals. The recognition and lysis of sensitive target cells (K562 cell line) by NK cells as well as stimulation of NK cells with IL-2 alone resulted in the release of significant levels of MIP- $1 \alpha$, MIP-1 $\beta$, and RANTES. Cross-linking of CD16 (FcyRIII) optimized CC-chemokine production from NK cells, resulting in levels of secretion comparable to or higher than those produced by CD3-cross-linked or PHAstimulated $\mathrm{CD}^{+} \mathrm{T}$ cells. Furthermore, CD16 cross-linked NK

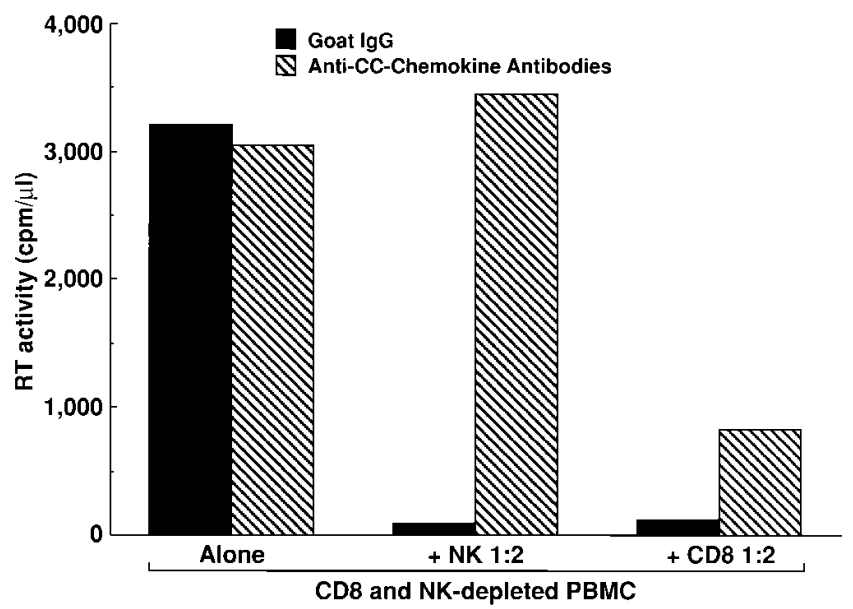

Figure 6. Effect of neutralizing antibodies to MIP-1 $\alpha$, MIP-1 $1 \beta$, and RANTES on NK cell-mediated and $\mathrm{CD} 8^{+} \mathrm{T}$ cell-mediated suppression of HIV replication. CD8/NK-depleted PBMC were cultured with PHA $(3 \mu \mathrm{g} / \mathrm{ml})+\mathrm{IL}-2(20 \mathrm{U} / \mathrm{ml})+\mathrm{IL}-4(5 \mathrm{ng} / \mathrm{ml})$ with or without the addition of autologous CD16 cross-linked NK or CD8 ${ }^{+} \mathrm{T}$ effector (ratio 1:2) cells in the presence of either goat anti-mouse IgG (control antibody, $110 \mu \mathrm{g} / \mathrm{ml}$ ) or neutralizing anti-CC-chemokine antibodies (anti-MIP- $1 \alpha$ [50 $\mu \mathrm{g} / \mathrm{ml}]$, anti-MIP-1 $\beta[50 \mu \mathrm{g} / \mathrm{ml}]$, antiRANTES $[10 \mu \mathrm{g} / \mathrm{ml}])$. The values refer to peak RT activity in culture supernatants. Similar results were obtained in cultures stimulated with anti-CD3 (mouse ascites, 1:4,000 dilution) + IL-2 (20 U/ml). These data are representative of two independent analyses. cells suppressed HIV replication in an autologous coculture system, in most cases as potently as did anti-CD3 or PHAstimulated $\mathrm{CD}^{+} \mathrm{T}$ cells. Finally, supernatants from CD16 cross-linked NK cells markedly inhibited the entry of an MT-2negative but not a MT-2 positive HIV strain into susceptible $\mathrm{CD}^{+} / \mathrm{CCR}^{+} / \mathrm{CXCR} 4^{+}$cells (PM1 cell line).

The first observation that MIP- $1 \alpha$, MIP-1 $\beta$, and RANTES interfere with HIV replication was made in a study designed to identify the soluble factor(s) involved in $\mathrm{CD} 8^{+} \mathrm{T}$ cell-mediated HIV suppression (12). Subsequent studies have demonstrated that in addition to $\mathrm{CD}^{+} \mathrm{T}$ cells, $\mathrm{CD}^{+}{ }^{+} \mathrm{T}$ cells and macrophages, as well as several other cell types, secrete CC-chemo-

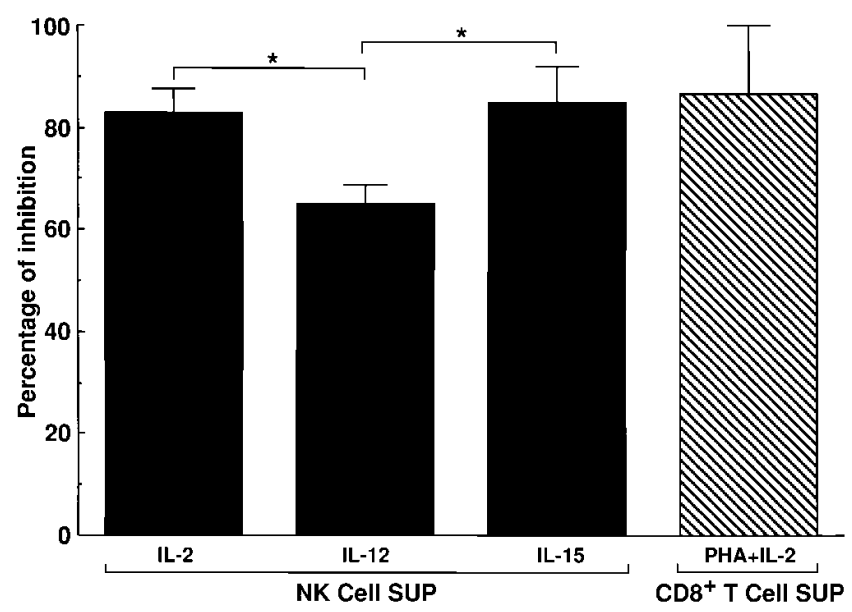

Figure 7. Supernatants from NK cells inhibit the entry of MT-2-negative strain of HIV-1. Supernatants were obtained by stimulating CD16 cross-linked NK cells with IL-2 (100 U/ml) $(n=9)$, IL-12 (100 $\mathrm{U} / \mathrm{ml})(n=4)$, or IL-15 $(100 \mathrm{U} / \mathrm{ml})(n=4)$. Supernatants derived from $\mathrm{CD}^{+} \mathrm{T}$ cells were obtained by stimulating the cells with PHA $(3 \mu \mathrm{g} / \mathrm{ml})+\mathrm{IL}-2(20 \mathrm{U} / \mathrm{ml})(n=3)$. Values are expressed as mean percentage of inhibition compared to the maximal level of entry detected in the positive control (cells pretreated with medium alone, washed after $6-7 \mathrm{~h}$ ). Statistical analysis to determine $P$ values was performed with the Student's $t$ test $\left({ }^{*} P<0.05\right)$. 
kines at levels capable of suppressing MT-2-negative HIV replication in vitro $(14,39,40)$. Of interest, the ability of PBMCs, $\mathrm{CD}^{+}{ }^{+} \mathrm{T}$ cells and/or $\mathrm{CD}^{+} \mathrm{T}$ cells to produce high levels of $\mathrm{CC}$-chemokines in vitro has been correlated with resistance to HIV infection (exposed uninfected individuals) $(41,42)$ and with nonprogression of HIV disease in HIV-infected subjects $(43,44)$. The present study is the first to demonstrate and characterize the capability of NK cells isolated from HIV-infected individuals to produce high levels of CC-chemokines. The observation that freshly isolated NK cells from HIV-infected and uninfected donors contain high copy numbers of MIP- $1 \alpha$ and RANTES mRNA (equal or greater than levels found in $\mathrm{CD}^{+}$ $\mathrm{T}$ cells) and that they secrete high levels of CC-chemokines in vitro suggests that NK cells may also be significant cellular sources of CC-chemokines in vivo. Analysis of the levels of intracellular CC-chemokine proteins in $\mathrm{NK}$ and $\mathrm{CD}^{+} \mathrm{T}$ cells ex vivo (on PBMCs, immediately after Ficoll-Hypaque separation or on whole blood, immediately after phlebotomy) is currently being conducted. Of particular interest, after in vitro culturing (3-5 d) NK cells produced significantly higher levels of CC-chemokines, both constitutively and in response to IL-2 alone, than did $\mathrm{CD}^{+} \mathrm{T}$ cells isolated from the same donors.

Under conditions designed to mimic in vivo activation of NK function, such as tumor cell killing (K562 lysis) and antibody-dependent cellular cytotoxicity (ADCC) via FcyRIII (CD16) cross-linking, NK cells were found to secrete significant levels of MIP- $1 \alpha$, MIP-1 $\beta$, and RANTES. Of interest, the ability of NK cells to secrete CC-chemokines upon recognition of tumor cell targets correlated with their ability to lyse target cells. The same phenomenon has been observed with $\mathrm{CD}^{+}$ HIV-specific cytotoxic T lymphocyte clones (45). CD16 crosslinking, both in untreated (for MIP- $1 \alpha$, MIP-1 $\beta$, and RANTES) and in IL-2-stimulated conditions (for MIP- $1 \alpha$ and RANTES), dramatically enhanced CC-chemokine production by NK cells. Moreover, the levels of secretion in response to IL-2 of MIP-1 $\alpha$ and RANTES from CD16 cross-linked NK cells were significantly higher than the levels detected in the supernatants obtained from CD3 cross-linked $\mathrm{CD}^{+} \mathrm{T}$ cells. These data suggest that NK cells may be one of the most important lymphocytic sources of CC-chemokines.

Activation of NK lytic activity, both by K562 target cell recognition and by CD16 cross-linking, is associated with the secretion of cytokines, such as TNF- $\alpha$ (46), which upregulate CC-chemokine gene expression $(47,48)$. In addition, it has been demonstrated that CD16 cross-linking induces the expression of the high affinity $\alpha$ chain of the IL-2 receptor (49), thus making NK cells more responsive to IL-2 with regard to increased lytic activity and production of cytokines and chemokines.

HIV infection is often associated with polyclonal B cell activation and hypergammaglobulinemia (50). In this regard, activation of NK cells via interaction between CD16 and gp120/ anti-gp120 antibody complexes likely occurs to a significant degree in vivo in HIV-infected individuals $(51,52)$.

Immunomodulatory cytokines, particularly IL-2 and IL-15, potently upregulated CC-chemokine production from CD16 cross-linked NK cells in vitro; an observation which may be relevant in the setting of cytokine-based immunotherapy for HIV disease (53-55). In this regard, decreases or stabilization of viremia in HIV-infected subjects receiving IL-2 therapy in conjunction with antiretroviral drugs as compared to subjects receiving antiretroviral therapy alone may be in part related to the ability of this cytokine to stimulate antiviral immune activities such as cytolytic activity (56) and perhaps the production of CC-chemokines (57) or other HIV-suppressive factors. The effect of in vivo administration of IL-2 on the production of CC-chemokines by NK cells and $\mathrm{CD}^{+} \mathrm{T}$ cells is currently under investigation.

The ability of IL-12, and particularly IL-15, to induce high levels of CC-chemokines from NK cells is of interest in view of the potential for NK-derived chemokines to interfere with HIV replication before the onset of antigen-specific immune responses and the production of IL-2. It will be important to determine whether CC-chemokine production by cells involved in early innate immune responses, such as macrophages and NK cells, plays a role in determining the level of viral replication and spread during primary HIV infection.

CD16 cross-linked NK cells were able to suppress HIV replication in an autologous coculture system at efficiencies comparable to those of $\mathrm{CD}^{+} \mathrm{T}$ cells in the majority of the patients tested. This property of NK cells has not been previously demonstrated while it has been well established for $\mathrm{CD}^{+}$cells (58). The majority of studies investigating the HIV suppressor activity of $\mathrm{CD}^{+}$cells have been performed using culture systems that optimize $\mathrm{T}$ cell activation, such as anti-CD3 or PHA. These conditions do not induce significant production of $\mathrm{CC}$ chemokines from NK cells contained in the $\mathrm{CD}^{+}$cell population as does CD16 cross-linking (data not shown). Thus, the potential for NK cell contribution to suppression of HIV replication in these anti-CD3 or PHA-stimulated $\mathrm{CD}^{+}$cell systems is probably underestimated and masked by the suppressor effects mediated by highly activated $\mathrm{CD}^{+} \mathrm{T}$ cells. Of interest, under in vitro conditions of stimulation with cytokines only, we have observed a higher frequency of HIV isolation from PBMC of HIV-infected subjects if $\mathrm{CD} 16^{+} \mathrm{CD} 56^{+}$cells were depleted from $\mathrm{PBMC}$ in addition to depletion of $\mathrm{CD}^{+} \mathrm{T}$ cells (Monaco, J., A. Oliva, and A.S. Fauci, unpublished observations).

The mechanisms involved in NK cell-mediated HIV suppression are likely complex. In $50 \%$ of the HIV-infected individuals tested, NK cell-mediated HIV suppression was completely abrogated by the addition of neutralizing antibodies directed against MIP- $1 \alpha$, MIP-1 $\beta$, and RANTES. The failure of neutralization of CC-chemokines to overcome HIV suppression in some NK cell cocultures, as well as in all $\mathrm{CD}^{+} \mathrm{T}$ cell cocultures, suggests that cell contact-dependent factors, such as lytic activity $(37,38)$, and/or other HIV suppressive cytokines $(35,58)$ may contribute to the inhibitory effect of NK cells and $\mathrm{CD}^{+} \mathrm{T}$ cells on HIV replication. Furthermore, activation of $\mathrm{NK}$ cells and $\mathrm{CD} 8^{+} \mathrm{T}$ cells can also result in the secretion of factors, such as TNF- $\alpha$, which can potentially induce HIV replication. Therefore, the balance of HIV-suppressive and HIV-inductive activities of NK cells and $\mathrm{CD}^{+} \mathrm{T}$ cells, likely determines the overall impact of these effector lymphocytes on HIV replication and pathogenesis.

The in vivo physiologic relevance of NK-derived CCchemokines in the pathogenesis and progression of HIV infection is unclear at present and requires further investigation. Although a trend toward decreasing HIV inhibitory activity was observed with NK cells obtained from individuals with more advanced disease, no statistically significant correlation between NK cell function and stage of disease was found in the present study. However, a protective role of NK cells against initial or primary HIV infection has been suggested recently in 
a study involving a Thailand cohort of highly exposed persistently seronegative women (HEPS) (5). The percentages and absolute numbers of NK cells were significantly higher in the HEPS women compared to age-matched seronegative women with short term exposure and to a reference Thai population.

In conclusion, NK cells are capable of secreting substantial amounts of CC-chemokines in response to physiologic activation signals such as cross-linking of their $\mathrm{Fc}$ receptors and lysis of sensitive target cells. Furthermore, CC-chemokine production from NK cells is significantly upregulated by CD16 crosslinking, IL-2, and IL-15. NK cells are potent suppressors of MT-2-negative HIV replication and may play an important role in the host defense against MT-2-negative strains of HIV-1, particularly during primary HIV infection.

\section{Acknowledgments}

We would like to thank Delia Goletti, Mario Ostrowski, Eileen Donoghue, and Jim Arthos for helpful discussions, Patricia Walsh for her excellent editorial assistance, and Joe Adelsberger for performing flow cytometry analyses.

Dr. Oliva is a recipient of a fellowship for AIDS research from the Istituto Superiore di Sanità, Rome, Italy.

\section{References}

1. Trinchieri, G. 1989. Biology of natural killer cells. Adv. Immunol. 47: 187-376.

2. Pape, G., M. Troye, B. Axelsson, and P. Perlmann. 1979. Simultaneous occurrence of immunoglobulin-dependent and immunoglobulin-independent mechanisms in natural cytotoxicity of human lymphocytes. J. Immunol. 122: 2251-2260.

3. Moretta, A., C. Bottino, M. Vitale, D. Pende, R. Biassoni, M.C. Mingari, and L. Moretta. 1996. Receptors for HLA class-I molecules in human natural killer cells. Anпu. Rev. Immunol. 14:619-648.

4. Lanier, L.L., and J.H. Phillips. 1996. Inhibitory MHC class I receptors on NK cells and T cells. Immunol. Today. 17:86-91.

5. Rungruengthanakit, K., A. Duerr, V. Suriyanon, L. Flowers, T. Nagachinta, A. Tansuhaj, D. Kunangern, M. de Boer, and K.E. Nelson. 1996. Immune parameters among highly exposed, persistently seronegative (HEPS) Thai women. Abstracts XI Int. Conference on AIDS. Mo.A.401a. (Abstr.) 1:13.

6. Shieh, T.M., D.L. Carter, K.R. Chadwick, J.B. Margolick, M.C. Zink, and J.E. Clements. 1998. Role of NK cells in control of acute SIV infection. Keystone Symposium-HIV Pathogenesis and Treatment. 102:4085a. (Abstr.)

7. Ratcliffe, L.T., P.T. Lukey, C.R. MacKenzie, and S.R. Ress. 1994. Reduced NK activity correlates with active disease in HIV-patients with multidrug-resistant pulmonary tuberculosis. Clin. Exp. Immunol. 97:373-379.

8. Brenner, B.G., M. Gornitsky, and M.A. Wainberg. 1994. Interleukin-2inducible natural immune (lymphokine-activated killer cell) responses as a functional correlate of progression to AIDS. Clin. Diagn. Lab. Immunol. 1: $538-544$

9. Ahmad, A., and J. Menezes. 1995. Positive correlation between the natural killer and gp120/41-specific antibody-dependent cellular cytotoxic effector functions in HIV-infected individuals. J. Acquired Immune Defic. Syndr. 10: $115-119$

10. Moore, J.P., A. Trkola, and T. Dragic. 1997. Co-receptors for HIV-1 entry. Curr. Opin. Immunol. 9:551-562.

11. D'Souza, M.P., and V.A. Harden. 1996. Chemokines and HIV-1 second receptors. Confluence of two fields generates optimism in AIDS research. Nat. Med. 2:1293-1300.

12. Cocchi, F., A.L. DeVico, A. Garzino-Demo, S.K. Arya, R.C. Gallo, and P. Lusso. 1995. Identification of RANTES, MIP-1 alpha, and MIP-1 beta as the major HIV-suppressive factors produced by $\mathrm{CD}^{+}$T cells. Science. 270:18111815.

13. Deng, H., R. Liu, W. Ellmeier, S. Choe, D. Unutmaz, M. Burkhart, P. Di Marzio, S. Marmon, R.E. Sutton, C.M. Hill, et al. 1996. Identification of a major co-receptor for primary isolates of HIV-1. Nature. 381:661-666.

14. Dragic, T., V. Litwin, G. Allaway, S. Martin, Y. Huang, K.A. Nagashima, C. Cayanan, P.J. Maddon, R.A. Koup, J.P. Moore, and W.A. Paxton. 1996. HIV-1 entry into $\mathrm{CD}^{+}{ }^{+}$cells is mediated by the chemokine receptor CCCKR-5. Nature. 381:667-673.

15. Alkhatib, G., C. Combadiere, C. Broder, Y. Feng, P. Kennedy, P. Murphy, and E.A. Berger. 1996. CC-CKR5: a RANTES, MIP-1 $\alpha$, MIP-1 $\beta$ receptor as a fusion cofactor for macrophage-tropic HIV-1. Science. 272:1955-1958.
16. Choe, H., M. Farzan, Y. Sun, N. Sullivan, B. Rollins, P.D. Ponath, L. Wu, C.R. Mackay, G. LaRosa, W. Newman, et al. 1996. The $\beta$-chemokine receptors CCR3 and CCR5 facilitate infection by primary HIV-1 isolates. Cell. 85:1135-1138

17. Doranz, B.J., J. Rucker, Y. Yi, R.J. Smyth, M. Samson, S.C. Peiper, M. Parmentier, R.G. Collman, and R.W. Doms. 1996. A dual-tropic primary HIV-1 isolate that uses fusin and the B-chemokine receptors CKR-5, CKR-3, and CKR-2b as fusion cofactors. Cell. 85:1149-1158.

18. Liu, R., W.A. Paxton, S. Choe, D. Ceradini, S.R. Martin, R. Horuk, M.E. MacDonald, H. Stuhlmann, R.A. Koup, and N.R. Landau. 1996. Homozygous defect in HIV-1 coreceptor accounts for resistance of some multiplyexposed individuals to HIV-1 infection. Cell. 86:367-377.

19. Samson, M., F. Libert, B.J. Doranz, J. Rucker, C. Liesnard, C.M. Farber, S. Saragosti, C. Lapoumeroulie, J. Cognaux, C. Forceille, et al. 1996. Resistance to HIV-1 infection in caucasian individuals bearing mutant alleles of the CCR-5 chemokine receptor gene. Nature. 382:722-725.

20. Eugen-Olsen, J., A.K. Iversen, P. Garred, U. Koppelhus, C. Pedersen, T.L. Benfield, A.M. Sorensen, T. Katzenstein, E. Dickmeiss, J. Gerstoft, et al. 1997. Heterozygosity for a deletion in the CKR-5 gene leads to prolonged AIDS-free survival and slower CD4 T-cell decline in a cohort of HIV-seropositive individuals. AIDS. 11:305-310.

21. Dean, M., M. Carrington, C. Winkler, G.A. Huttley, M.W. Smith, R. Allikmets, J.J. Goedert, S.P. Buchbinder, E. Vittinghoff, E. Gomperts, et al. 1996. Genetic restriction of HIV-1 infection and progression to AIDS by a deletion allele of the CKR5 structural gene. Science. 273:1856-1862.

22. Huang, Y., W.A. Paxton, S.M. Wolinsky, A.U. Neumann, L. Zhang, T. He, S. Kang, D. Ceradini, Z. Jin, K. Yazdanbakhsh, et al. 1996. The role of a mutant CCR5 allele in HIV-1 transmission and disease progression. Nat. Med. 2:1240-1243.

23. Michael, N.L., G. Chang, L.G. Louie, J.R. Mascola, D. Dondero, D.L. Birx, and H.W. Sheppard. 1997. The role of viral phenotype and CCR-5 gene defects in HIV-1 transmission and disease progression. Nat. Med. 3:338-340.

24. Bluman, E.M., K.J. Bartynski, B.R. Avalos, and M.A. Caligiuri. 1996. Human natural killer cells produce abundant macrophage inflammatory protein-1 alpha in response to monocyte-derived cytokines. J. Clin. Invest. 97:27222727.

25. Kievits, T., B. van Gemen, D. van Strijp, R. Schukkink, M. Dircks, H Adriaanse, L. Malek, R. Sooknanan, and P. Lens. 1991. NASBA ${ }^{\mathrm{TM}}$ isothermal enzymatic in vitro nucleic acid amplification optimized for the diagnosis of HIV-1 infection. J. Virol. Methods. 35:273-286.

26. Romano, J.W., K.G. Williams, R.N. Shurtliff, C. Ginocchio, and M. Kaplan. 1997. NASBA technology: isothermal RNA amplification in qualitative and quantitative diagnostics. Immunol. Invest. 26:15-28.

27. Willey, R.L., D.H. Smith, L.A. Lasky, T.S. Theodore, P.L. Earl, B. Moss, D.J. Capon, and M.A. Martin. 1988. In vitro mutagenesis identifies a region within the envelope gene of the human immunodeficiency virus that is critical for infectivity. J. Virol. 62:139-147.

28. Zack, J.A., S.J. Arrigo, S.R. Weitsman, A.S. Go, A. Haislip, and I.S.Y. Chen. 1990. HIV-1 entry into quiescent primary lymphocytes: molecular analysis reveals a labile, latent viral structure. Cell. 61:213-222.

29. Trinchieri, G., and N. Valiante. 1993. Receptors for the Fc fragment of IgG on natural killer cells. Nat. Immun. 12:218-234.

30. van Lier, R.A., M. Brouwer, V.I. Rebel, C.J. van Noesel, and L.A. Aarden. 1989. Immobilized anti-CD3 monoclonal antibodies induce accessory cell-independent lymphokine production, proliferation and helper activity in human T lymphocytes. Immunology. 68:45-50.

31. Trinchieri, G., M. Matsumoto-Kobayashi, S.C. Clark, J. Seehra, L. London, and B. Perussia. 1984. Response of resting human peripheral blood natural killer cells to interleukin 2. J. Exp. Med. 160:1147-1169.

32. Robertson, M.J., R.J. Soiffer, S.F. Wolf, T.J. Manley, C. Donahue, D. Young, S.H. Herrmann, and J. Ritz. 1992. Response of human natural killer (NK) cells to NK cell stimulatory factor (NKSF): cytolytic activity and proliferation of NK cells are differentially regulated by NKSF. J. Exp. Med. 175:779-788.

33. Carson, W.E., J.G. Giri, M.J. Lindemann, M.L. Linett, M. Ahdieh, R. Paxton, D. Anderson, J. Eisenmann, K. Grabstein, and M.A. Caligiuri. 1994 Interleukin (IL) 15 is a novel cytokine that activates human natural killer cells via components of the IL-2 receptor. J. Exp. Med. 180:1395-1403.

34. Walker, C.M., D.J. Moody, D.P. Stites, and J.A. Levy. 1986. CD8 ${ }^{+}$lymphocytes can control HIV infection in vitro by suppressing virus replication. Science. 234:1563-1566.

35. Moriuchi, H., M. Moriuchi, C. Combadiere, P.M. Murphy, and A.S Fauci. 1996. CD8 ${ }^{+} \mathrm{T}$ cell-derived soluble factor(s), but not beta-chemokines RANTES, MIP-1 alpha, and MIP-1 beta, suppress HIV-1 replication in monocyte/macrophages. Proc. Natl. Acad. Sci. USA. 93:15341-15345.

36. Levy, J.A., C.E. Mackewicz, and E. Barker. 1996. Controlling HIV pathogenesis: the role of the noncytotoxic anti-HIV response of $\mathrm{CD}^{+} \mathrm{T}$ cells Immunol. Today. 17:217-224.

37. Yang, O.O., and B.D. Walker. 1997. CD8 ${ }^{+}$cells in human immunodeficiency virus type I pathogenesis: cytolytic and noncytolytic inhibition of viral replication. Adv. Immunol. 66:273-311.

38. Ruscetti, F.W., J.A. Mikovits, V.S. Kalyanaraman, R. Overton, H. Stevenson, K. Stromberg, R.B. Herberman, W.L. Farrar, and J.R. Ortaldo. 
1986. Analysis of effector mechanisms against HTLV-I- and HTLV-III/LAVinfected lymphoid cells. J. Immunol. 136:3619-3624.

39. Kinter, A.L., M. Ostrowski, D. Goletti, A. Oliva, D. Weissman, K. Gantt, E. Hardy, R. Jackson, L. Ehler, and A.S. Fauci. 1996. HIV replication in $\mathrm{CD}^{+}{ }^{+} \mathrm{T}$ cells of HIV-infected individuals is regulated by a balance between the viral suppressive effects of endogenous beta-chemokines and the viral inductive effects of other endogenous cytokines. Proc. Natl. Acad. Sci. USA. 93:1407614081.

40. Verani, A., G. Scarlatti, M. Comar, E. Tresoldi, S. Polo, M. Giacca, P. Lusso, A.G. Siccardi, and D. Vercelli. 1997. C-C chemokines released by lipopolysaccharide (LPS)-stimulated human macrophages suppress HIV-1 infection in both macrophages and T cells. J. Exp. Med. 185:805-816.

41. Furci, L., G. Scarlatti, S. Burastero, G. Tambussi, C. Colognesi, C. Quillent, R. Longhi, P. Loverro, B. Borgonovo, D. Gaffi, et al. 1997. Antigen-driven C-C chemokine-mediated HIV-1 suppression by $\mathrm{CD}^{+} \mathrm{T}$ cells from exposed uninfected individuals expressing the wild-type CCR-5 allele. J. Exp. Med. 186: 455-460.

42. Zagury, D., A. Lachgar, V. Chams, L.S. Fall, J. Bernard, J.-F. Zagury, B. Bizzini, A. Gringeri, E. Santagostino, J. Rappaport, et al. 1998. C-C chemokines, pivotal in protection against HIV type 1 infection. Proc. Natl. Acad. Sci. USA. 95:3857-3861.

43. Scala, E., G. D’Offizi, R. Rosso, O. Turriziani, R. Ferrara, A.M. Mazzone, G. Antonelli, F. Aiuti, and R. Paganelli. 1997. C-C chemokines, IL-16, and soluble antiviral factor activity are increased in cloned $\mathrm{T}$ cells from subjects with long-term non-progressive HIV infection. J. Immunol. 158:4485-4492.

44. Saha, K., G. Bentsman, L. Chess, and D.J. Volsky. 1998. Endogenous production of beta-chemokines by $\mathrm{CD}^{+}$, but not $\mathrm{CD}^{+}$, T-cell clones correlates with the clinical state of human immunodeficiency virus type 1 (HIV-1)infected individuals and may be responsible for blocking infection with nonsyncytium-inducing HIV-1 in vitro. J. Virol. 72:876-881.

45. Wagner, L., O.O. Yang, E.A. Garcia-Zepeda, Y. Ge, S.A. Kalams, B.D. Walker, M.S. Pasternack, and A.D. Luster. 1998. Beta-chemokines are released from HIV-1-specific cytolytic T-cell granules complexed to proteoglycans. $\mathrm{Na}$ ture. 391:908-911.

46. Jewett, A., X.H. Gan, L.T. Lebow, and B. Bonavida. 1996. Differential secretion of TNF-alpha and IFN-gamma by human peripheral blood-derived NK subsets and association with functional maturation. J. Clin. Immunol. 16: $46-54$

47. Moriuchi, H., M. Moriuchi, and A.S. Fauci. 1997. Nuclear factor-kappa B potently upregulates the promoter activity of RANTES, a chemokine that blocks HIV infection. J. Immunol. 158:3483-3491.
48. Nelson, P.J., B.D. Ortiz, J.M. Pattison, and A.M. Krensky. 1996. Identification of a novel regulatory region critical for expression of the RANTES chemokine in activated T lymphocytes. J. Immunol. 157:1139-1148.

49. Anegon, I., M.C. Cuturi, G. Trinchieri, and B. Perussia. 1988. Interaction of Fcy receptor (CD16) with ligands induces transcription of IL-2 recepto (CD25) and lymphokine genes and expression of their products in human natural killer cells. J. Exp. Med. 167:452-472.

50. Lane, H.C., H. Masur, L. Edgard, G. Whalen, A. Rook, and A.S. Fauci. 1983. Abnormalities of B-cell activation and immunoregulation in patients with the acquired immunodeficiency syndrome. N. Engl. J. Med. 309:453-458.

51. Rook, A.H., H.C. Lane, T. Folks, S. McCoy, H. Alter, and A.S. Fauci. 1987. Sera from HTLV-III/LAV antibody-positive individuals mediate antibody-dependent cellular cytotoxicity against HTLV-III/LAV-infected T cells. J. Immunol. 138:1064-1067.

52. Amadori, A., G. De Silvestro, R. Zamarchi, M.L. Veronese, M.R. Mazza, G. Schiavo, M. Panozzo, A. De Rossi, L. Ometto, J. Mous, et al. 1992. CD4 epitope masking by gp120/anti-gp120 antibody complexes. A potential mechanism for $\mathrm{CD}^{+}$cell function down-regulation in AIDS patients. J. Immunol. 148:2709-2716.

53. Kovacs, J.A., S. Vogel, J.M. Albert, J. Falloon, R.T. Davey, Jr., R.E. Walker, M.A. Polis, K. Spooner, J.A. Metcalf, M. Baseler, et al. 1996. Controlled trial of interleukin-2 infusions in patients infected with the human immunodeficiency virus. N. Engl. J. Med. 335:1350-1356.

54. Clerici, M., D.R. Lucey, J.A. Berzofsky, L.A. Pinto, T.A. Wynn, S.P. Blatt, M.J. Dolan, C.W. Hendrix, S.F. Wolf, and G.M. Shearer. 1993. Restoration of HIV-specific cell-mediated immune responses by interleukin-12 in vitro. Science. 262:1721-1724.

55. Chehimi, J., J.D. Marshall, O. Salvucci, I. Frank, S. Chehimi, S. Kawecki, D. Bacheller, S. Rifat, and S. Chouaib. 1997. IL-15 enhances immune functions during HIV infection. J. Immunol. 158:5978-5987.

56. Schwartz, D.H., G. Skowron, and T.C. Merigan. 1991. Safety and effects of interleukin-2 plus zidovudine in asymptomatic individuals infected with human immunodeficiency virus. J. Acquired Immune Defic. Syndr. 4:11-23.

57. De Paoli, P., S. Zanussi, C. Simonelli, M.T. Bortolin, M. D'Andrea, C. Crepaldi, R. Talamini, M. Comar, M. Giacca, and U. Tirelli. 1997. Effects of subcutaneous interleukin-2 therapy on CD4 subsets and in vitro production in HIV+ subjects. J. Clin. Invest. 100:2737-2743.

58. Pal, R., A. Garzino-Demo, P.D. Markham, J. Burns, M. Brown, R.C Gallo, and A.L. DeVico. 1997. Inhibition of HIV-1 infection by the $\beta$-chemokine MDC. Science. 278:695-698. 